\title{
PENINGKATAN HASIL BELAJAR SISWA MELALUI MODEL PEMBELAJARAN KOOPERATIF TIPE STUDENT TEAM ACHIEVEMENT DIVISION (STAD) PADA MATERI GELOMBANG MEKANIK
}

\author{
Laila Wahyuni \\ Guru SMA Negeri 1 Mutiara \\ e-mail: Lailawahyuni79@gmail.com
}

\begin{abstract}
Abstrak: Penelitian ini bertujuan untuk mengetahui peningkatan hasil belajar materi Gelombang mekanik dengan menggunakan pembelajaran kooperatif learning model STAD pada Siswa kelas XI MIPA.6 semester II SMA Negeri 1 Mutiara tahun pelajaran 2019/2020. Metode penelitian ini adalah Penelitian Tindakan Kelas (PTK) yang terdiri dari dua siklus, yaitu siklus I dan sklus II. Subyek pada penelitian ini adalah Siswa kelas XI MIPA.6 SMA Negeri 1 Mutiara dengan jumlah Siswa didalam kelas adalah 31 Siswa, terdiri dari 23 orang Siswa perempuan dan orang 8 Siswa laki-laki. Data penelitian diperoleh dengan observasi, dokumentasi, wawancara, dan tes. Hasil penilaian yang diperoleh adanya peningkatan jumlah siswa yang mencapai kriteria ketuntasan minimal (KKM) dengan nilai $\geq 75$ dari satu siklus ke siklus yang lain, dan terdapat peningkatan rata-rata hasil ulangan akhir siklus. Sehingga dapat dikatakan pembelajaran dengan pendekatan coorperatif learning model STAD pada materi gelombang mekanik dapat meningkatkan hasil belajar Siswa Kelas XI MIPA.6 semester II SMA Negeri 1 Mutiara.
\end{abstract}

Kata Kunci: Hasil Belajar, Model Pembelajaran Kooperatif, Tipe Student Team Achievement Division (STAD)

\section{IMPROVING LEARNING OUTCOMES ON MECHANICAL WAVE MATERIAL USING A COOPERATIVE LEARNING MODEL TYPE STUDENT TEAM ACHIEVEMENT DIVISION (STAD)}

\begin{abstract}
This study aims to determine the increase in learning outcomes of mechanical wave material by using the STAD model of cooperative learning in class XI MIPA.6 second semester students of SMA Negeri 1 Mutiara in the 2019/2020 academic year. This research method is Classroom Action Research (CAR) which consists of two cycles, namely cycle I and cycle II. The subjects in this study were students of class XI MIPA.6 SMA Negeri 1 Mutiara with the number of students in the class were 31 students, consisting of 23 female students and 8 male students. Research data obtained by observation, documentation, interviews, and tests. The results of the assessment obtained were an increase in the number of students who achieved the minimum completeness criteria (KKM) with a value of $\geq 75$ from one cycle to another, and there was an increase in the average test results at the end of the cycle. So it can be said that learning with the STAD coorperative learning approach on mechanical wave material can improve the learning outcomes of Class XI MIPA.6 students in semester II of SMA Negeri 1 Mutiara.
\end{abstract}

Keywords: Learning Outcomes, Cooperative Learning Model, Type Student Team Achievement Division (STAD) 


\section{PENDAHULUAN}

Banyak pihak mensinyalir bahwa rendahnya mutu pendidikan saat ini berkaitan erat dengan rendahnya motivasi Siswa dalam belajar. Tuntutan dalam dunia pendidikan sudah banyak berubah, kita tidak bisa lagi mempertahankan paradigma lama yaitu teacher center (pembelajaran berpusat pada Guru, sebagian besar Siswa cenderung pasif). Namun demikain hal ini nampaknya masih banyak diterapkan dalam proses pembelajaran di kelas dengan alasan pembelajaran seperti ini adalah praktis dan tidak menyita waktu. Keberhasilan proses pembelajaran merupakan hal utama yang didambakan oleh semua pihak, dalam pelaksanaan pendidikan di sekolah. Dalam proses pembelajaran, komponen utama adalah Guru dan Siswa. Agar proses pembelajaran berhasil, Guru harus membimbing Siswa dengan sungguh-sungguh. Oleh karena itu dalam pemilihan metode belajar harus cocok dengan materi dan kondisi, karena metode pembelajaran merupakan interaksi antara Guru dan Siswa dalam kegiatan belajar mengajar.

Penggunaan metode yang kurang tepat dapat menimbulkan kebosanan, kurang dipahami dan cendrung monoton, sehingga Siswa tidak termotivasi untuk belajar, khususnya dalam belajar fisika yang bersifat abstrak, sehingga sulit diterima dan dipahami, hal ini menyebabkan Siswa lebih banyak pasif dan menjadi apatis sehingga hasil belajarnya tidak optimal. Dalam proses pembelajaran sering kali dijumpai adanya kecenderungan Siswa yang tidak mau bertanya dalam kegiatan belajar mengajar, meskipun sebenarnya mereka belum mengerti materi yang diajarkan. Strategi yang sering digunakan oleh Guru untuk mengaktifkan Siswa adalah melibatkan Siswa dalam diskusi. Tetapi strategi ini juga tidak maksimal, walaupun Guru sudah mendorong Siswa untuk berpartisipasi. Kebanyakan Siswa terpaku menjadi penonton, sementara arena diskusi hanya dikuasai segelintir Siswa yang aktif. Suasana kelas perlu direncanakan dan dibangun sedemikian rupa sehingga Siswa mendapatkan kesempatan untuk berinteraksi satu sama lain.

Guru perlu menciptakan suasana belajar dimana Siswa bekerjasama secara gotong royong, pengembangan pembelajaran yang diperlukan saat ini adalah pembelajaran yang inovatif dan kreatif yang memberikan iklim kondusif dalam pengembangan daya nalar dan kreatifitas Siswa. Usaha Guru untuk mencapai tujuan pembelajaran antara lain, memilih metode yang tepat sesuai dengan materi, sehingga terciptanya kegiatan belajar mengajar yang kondusif. Salah satunya adalah dengan menggunakan metode pembelajaran kooperatif, yaitu belajar mengajar dengan jalan mengelompokkan Siswa dengan tingkat kemampuan yang berbeda ke dalam kelompok-kelompok kecil. Dalam kegiatan belajar mengajar yang ada di sekolah selama ini, sebenarnya sudah menerapkan belajar kelompok, namun, kegiatan kelompok tersebut cenderung hanya menyelesaikan tugas. Siswa yang berkemampuan rendah kurang berperan dalam mengerjakan tugas. Sedangkan pada pembelajaran kooperatif tujuan kelompok tidak hanya menyelesaikan tugas yang diberikan, tetapi juga memastikan bahwa setiap kelompok menguasai tugas yang diterimanya.

Ada berbagai jenis metode pembelajaran kooperatif, diantaranya adalah metode pembelajaran kooperatif tipe TGT (Teams Games Tournaments) dan metode pembelajaran kooperatif tipe STAD (Student Teams Achievement Division). Metode pembelajaran kooperatif tipe TGT merupakan salah satu model pembelajaran kooperatif dengan dibentuk kelompokkelompok kecil dalam kelas yang terdiri 5-6 Siswa yang heterogen, baik prestasi akademik, jenis kelamin, ras ataupun etnis. Metode pembelajaran kooperatif tipe STAD adalah salah satu tipe pembelajaran kooperatif yang paling sederhana dan sebuah cara yang bagus untuk digunakan dalam pembelajaran (Artini, 2020). Metode STAD merupakan suatu strategi belajar yang menghendaki Siswa belajar dalam kelompok yang beranggotakan 5-6 Siswa yang kemampuan akademiknya tinggi, sedang dan rendah. Tiap Siswa dalam kelompok memiliki tugas berbeda. Berdasarkan hasil penelitian (Rizal et al., 2021) menyimpulkan bahwa hasil 
belajar Siswa yang menggunakan metode kooperatif tipe STAD lebih baik daripada dengan metode konvensional. Sehingga dapat disimpulkan bahwa pembelajaran dengan menggunakan metode kooperatif STAD memberikan hasil belajar yang lebih baik daripada dengan metode konvensional (Esminarto et al., 2016).

Bertumpu pada kenyataan diatas, untuk meningkatkan hasil belajar fisika Guru harus mengganti model pembelajaran kovensional dengan model pembelajaran yang lebih kreatif dan inovatif yaitu kooperatif learning model STAD. Melalui pembelajaran model STAD, Guru dapat memancing kreatifitas dan interaksi Siswa dalam proses pembelajaran, dimana Siswa akan saling bekerjasama dan saling membantu dalam menguasai materi pembelajaran guna mencapai hasil belajar yang maksimal.

Berdasarkan uraian diatas, maka penulis ingin melakukan suatu penelitian yang berjudul "Meningkatkan hasil belajar fisika Siswa kelas XI MIPA.6 Semester II pada materi gelombang mekanik menggunakan model pembelajaran kooperatif tipe STAD (Student Team Achievement Division) di SMA Negeri 1 Mutiara Tahun Pelajaran 2019/2020".

\section{METODE}

Penelitian dilakukan selama 3 bulan, mulai dari bulan Januari sampai dengan bulan Maret 2019. Pelaksanaan penelitian dilakukan pada hari-hari efektif sekolah sesuai dengan roster pelajaran. Tempat dilaksanakan penelitian adalah SMA Negeri 1 Mutiara kelas XI. MIPA.6 tempat peneliti bertugas. Subyek pada penelitian ini adalah Siswa kelas XI MIPA.6 SMA Negeri 1 Mutiara dengan jumlah Siswa didalam kelas adalah 31 Siswa, terdiri dari 23 orang Siswa perempuan dan orang 8 Siswa laki-laki. Sumber data dalam penelitian ini adalah nilai hasil tes Siswa SMA Negeri 1 Mutiara Kelas XI MIPA.6 sebagai subjek penelitian. Data yang dikumpulkan dari Siswa meliputi data hasil tes tertulis. Tes tertulis dilaksanakan pada setiap hari akhir siklus yang terdiri atas materi gelombang mekanik. Selain Siswa sebagai sumber data, penulis juga menggunakan teman sejawat sesama Guru sebagai sumber data.

Teknik pengumpulan data dalam penelitian ini menggunakan teknik tes dan non tes. Tes tertulis digunakan pada akhir siklus I dan II pada materi gelombang mekanik. Untuk mengetahui aktivitas Siswa dgunakan tehnik non tes, meliputi teknik observasi, dokumentasi dan wawancara. Observasi digunakan pada saat pelaksanaan penelitian tindakan kelas pada siklus I dan II. Teknik dokumentasi digunakan untuk mengumpulkan data khususnya nilai mata pelajaran fisika. Sedangkan wawancara digunakan untuk mengetahui secara langsung perasaan Siswa saat pembelajaran berlangsung. Alat pengumpulan data meliputi :

1. Tes tertulis atas 5 butir soal

2. Non Tes, meliputi lembar observasi, wawancara dan dokumen.

Validasi data meliputi validasi hasil belajar dan validasi proses pembelajaran.

1. Validasi Hasil Belajar

Validasi hasil belajar dikenakan pada instrumen penelitian yang berupa tes. Validasi ini meliputi validasi teoritis dan validasi empiris. Validasi teoritis artinya mengadakan analisis instrumen yang terdiri atas face validity (tampilan tes), content validity (validitas isi). Validitas empiris artinya analisis terhadap butir-butir tes, yang dimulai dari perbuatan kisi-kisi soal, penulisan butir-butir soal, kunci jawaban dan kriteria pemberian skor.

2. Validasi proses pembelajaran

Validasi proses pembelajaran dilakukan dengan teknik triangulasi yang meliputi yaitu triangulasi sumber dan triangulasi metode. Triangulasi sumber dilakukan dengan observasi terhadap subyek penelitian yaitu Siswa Kelas XI MIPA.6 SMA Negeri 1 Mutiara dan kolaborasi dengan teman sejawat yang mengajar mata pelajaran fisika. Triangulasi metode 
dilakukan dengan penggunaan metode dokumentasi dan wawancara selain metode observasi. Metode dokumentasi dan wawancara digunakan untuk memperoleh data pendukung yang diperlukan dalam proses pembelajaran fisika.

Analisis data yang digunakan dalam penelitian ini adalah teknik analisis deskriptif, yang meliputi :

1. Analisis deskriptif komparatif hasil belajar dengan cara membandingkan hasil belajar siswa pada siklus I dan siklus II.

2. Analisis deskriptif kualitatif hasil observasi dengan cara membandingkan hasil observasi dan refleksi pada siklus I dan siklus II.

Indikator keberhasilan penelitian ini dengan menggunakan nilai hasil belajar dibandingkan dengan Kriteria Ketuntasan Minimal (KKM) yang ditetapkan sekolah sebesar 75. Prosedur penelitian merupakan Penelitian Tindakan Kelas (PTK) Kemmis dalam (Richiati, 2008) Penelitian Tindakan Kelas adalah sebuah bentuk inkuiri reflektif yang dilakukan secara kemitraan mengenai situasi sosial tertentu (termasuk pendidikan) untuk meningkatkan rasionalitas dan keadilan dari kegiatan praktek sosial. Rancangan siklus pada penelitian ini dapat digambarkan pada gambar dibawah ini:

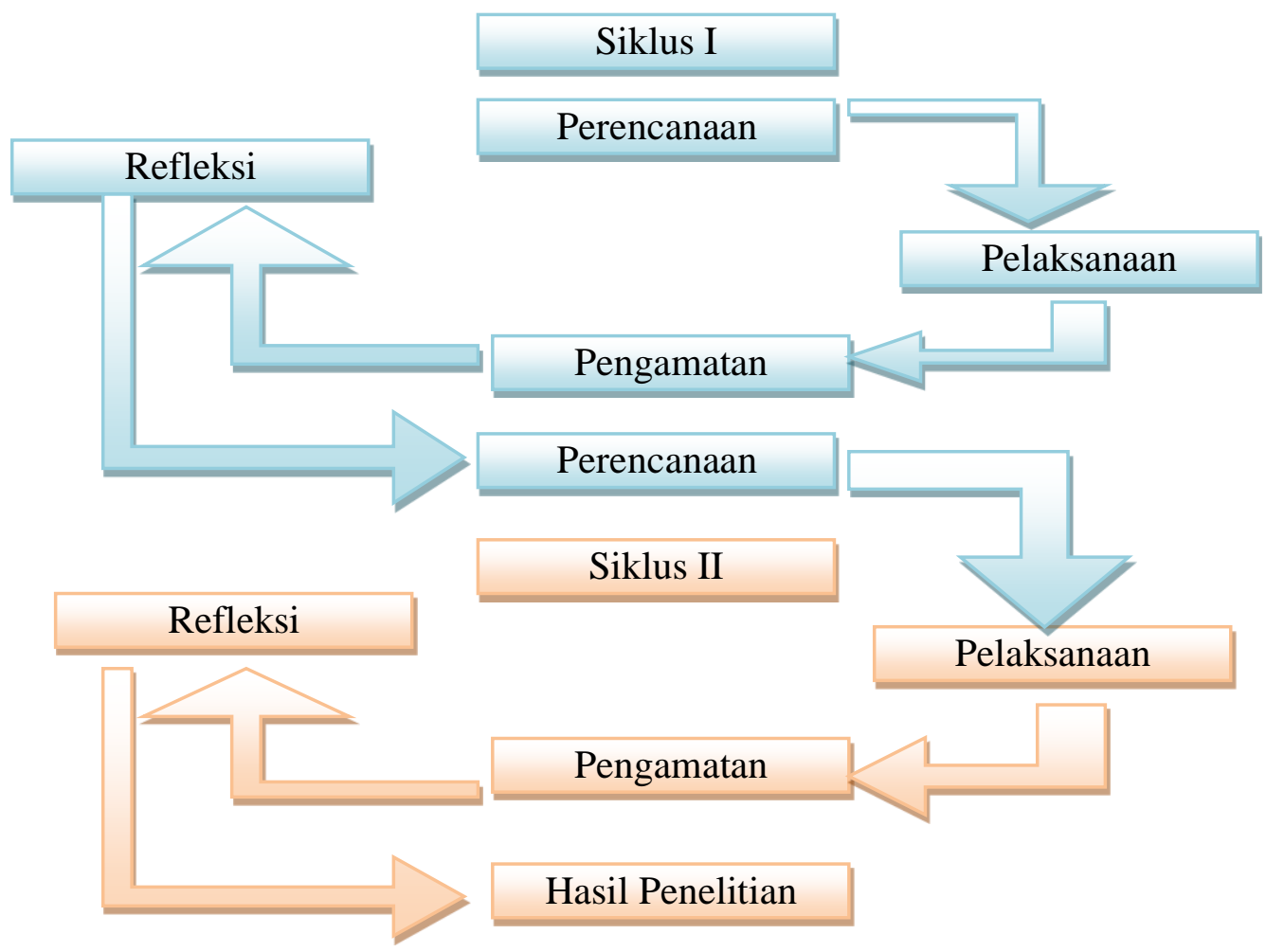

Gambar 1. Rancangan Siklus Penelitian

Penelitian ini terdiri atas 2 siklus. Setiap siklus terdiri atas perencanaan, pelaksanaan, dan rekfleksi.

1. Siklus I 
a. Perencanaan (planing), terdiri atas kegiatan :

1) Penyusunan Rencana Pelaksanaan Pembelajaran (RPP).

2) Menyiapkan LKS.

3) Membuat soal tes akhir pembelajaran.

Pelaksanaan (acting), terdiri atas atas kegiatan :

1) Pelaksanaan program pembelajaran sesuai dengan jadwal.

2) Membagi Siswa dalam kelompok belajar.

3) Proses pembelajaran dengan mengguna pembelajaran kooperatif learning model STAD pada materi gelombang mekanik.

4) Secara klasikal menjelaskan langkah-langkah dalam pembelajaran kooperatif learning model STAD dilengkapi lembar kerja Siswa.

5) Siswa menyelesaikan LKS dengan berdiskusi bersama kelompoknya masingmasing.

6) Mengadakan observasi tentang proses pembelajaran.

7) Mengadakan tes tertulis.

8) Penilaian hasil tes tertulis.

b. Pengamatan (observing)

Yaitu mengamati proses pembelajaran dan menilai hasil tes sehingga diketahui hasilnya. Atas dasar hasil tersebut digunakan untuk merencanakan tindak lanjut pada siklus berikutnya.

c. Refleksi (reflecting)

Yaitu menyimpulkan pelaksanaan hasil pelaksanaan pada siklus I.

2. Siklus II

a. Perencanaaan (planning), terdiri dari atas kegiatan :

1) Penyusunan Rencana Pelaksanaan Pembelajaran (RPP).

2) Menyiapkan LKS.

3) Menyiapkan soal tes.

b. Pelaksanaan (acting), terdiri atas atas kegiatan :

1) Pelaksanaan program pembelajaran sesuai dengan jadwal.

2) Membagi Siswa dalam kelompok belajar.

3) Proses pembelajaran dengan mengguna pembelajaran kooperatif learning model STAD pada materi gelombang mekanik.

4) Siswa menyelesaikan LKS dengan berdiskusi bersama kelompoknya.

5) Mengadakan observasi tentang proses pembelajaran.

6) Mengadakan tes tertulis.

7) Penilaian hasil tes tertulis.

c. Pengamatan (observing)

Yaitu mengamati proses pembelajaran dan menilai hasil tes sehingga diketahui hasilnya.

d. Refleksi (reflecting)

Yaitu menyimpulkan pelaksanaan hasil kegiatan pada siklus II. 


\section{HASIL DAN PEMBAHASAN}

\section{Hasil}

a. Deskripsi Hasil Siklus I

1. Perencanaan Tindakan

Tahap perencanaan pada siklus I dihasilkan beberapa perangkat pembelajaran dan instrumen penelitian. Perangkat pembelajaran yang dihasilkan adalah Rencana Pelaksanaan Pembelajaran (RPP), Buku Siswa (merupakan kumpulan lembar ahli), Buku Guru, dan Lembar Kegiatan Siswa (LKS). Adapun materi yang dibahas dalam perangkat pembelajaran tersebut adalah menjelaskan gelombang mekanik. Langkahlangkah pembelajaran yang disusun dalam RPP didesain sesuai dengan langkahlangkah dengan menggunakan metode STAD.

2. Pelaksanaan tindakan

Tahap ini merupakan pelaksanaan dari RPP yang sudah didesain sehingga sesuai dengan penggunaan metode STAD.

3. Hasil pengamatan (Observasi)

Observasi dilaksanakan pada keseluruhan kegiatan tatap muka, observasi dilakukan oleh observer yaitu teman sejawat pada SMA Negeri 1 Mutiara. Hasil pengamatan pada siklus I dapat dideskripsikan pada sebagai berikut:

1) Pertemuan 1

Nilai hasil belajar pada pertemuan I dapat dilihat pada tabel 1 sebagai berikut :

Tabel 1. Nilai Hasil Belajar Siklus I Pertemuan I

\begin{tabular}{cccccc}
\hline No & $\begin{array}{c}\text { Hasil } \\
\text { (angka) }\end{array}$ & $\begin{array}{c}\text { Hasil } \\
\text { (huruf) }\end{array}$ & $\begin{array}{c}\text { Arti } \\
\text { Lambang }\end{array}$ & $\begin{array}{c}\text { Jumlah } \\
\text { Siswa }\end{array}$ & Persen \\
\hline 1 & $85-100$ & A & Sangat baik & - & - \\
2 & $75-84$ & B & Baik & 22 & $70,79 \%$ \\
3 & $65-74$ & C & Cukup & 7 & $29,03 \%$ \\
4 & $55-64$ & D & Kurang & - & - \\
5 & $<54$ & E & $\begin{array}{c}\text { Sangat } \\
\text { kurang }\end{array}$ & - & - \\
\hline \multicolumn{7}{c}{ Jumlah } & $\mathbf{3 1}$ & $\mathbf{1 0 0 \%}$ \\
\hline
\end{tabular}

Berdasarkan tabel 1 diperoleh 22 Siswa (70,79\%) mendapatkan nilai B, 7 Siswa $(29,03 \%)$ mendapatkan nilai C

2) Pertemuan 2

Nilai hasil belajar pada pertemuan II dapat dilihat pada tabel 2 sebagai berikut :

Tabel 2. Nilai Hasil Belajar Siklus I Pertemuan II

\begin{tabular}{cccccc}
\hline No & $\begin{array}{c}\text { Hasil } \\
\text { (angka) }\end{array}$ & $\begin{array}{c}\text { Hasil } \\
\text { (huruf) }\end{array}$ & Arti Lambang & $\begin{array}{c}\text { Jumlah } \\
\text { Siswa }\end{array}$ & Persen \\
\hline 1 & $85-100$ & A & Sangat baik & - & - \\
2 & $75-84$ & B & Baik & 26 & $84 \%$ \\
3 & $65-74$ & C & Cukup & 5 & $16 \%$ \\
4 & $55-64$ & D & Kurang & - & -
\end{tabular}




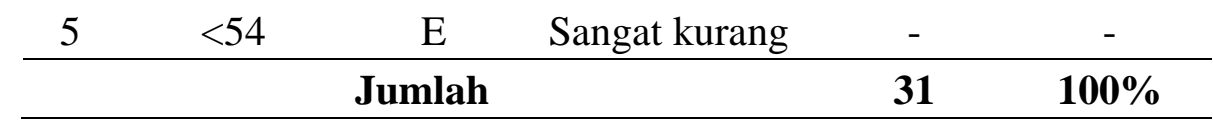

Berdasarkan tabel 2 diperoleh 26 Siswa (84\%) mendapatkan nilai B, 5 Siswa (16\%) mendapatkan nilai $\mathrm{C}$.

4. Refleksi

Nilai ketuntasan Siswa pada siklus I, pertemuan pertama dan kedua dapat dilihat pada tabel 3 sebagai berikut :

Tabel 3. Nilai ketuntasan siklus I pertemuan I pertemuan II

\begin{tabular}{clcccc}
\hline \multirow{2}{*}{ No } & \multirow{2}{*}{ Ketuntasan } & \multicolumn{2}{c}{ PETEMUAN I } & \multicolumn{2}{c}{ PETEMUAN II } \\
& & Jumlah & Persen & & \\
\hline 1 & Tuntas & 22 & $70,97 \%$ & 1 & $\begin{array}{l}\text { Tuntas } \\
\text { Delum }\end{array}$ \\
\cline { 2 - 3 } & $\begin{array}{l}\text { Belum } \\
\text { tuntas }\end{array}$ & 9 & $29,03 \%$ & 2 & $\begin{array}{l}\text { Belum } \\
\text { tuntas }\end{array}$ \\
\hline & Jumlah & $\mathbf{3 1}$ & $\mathbf{1 0 0 \%}$ & $\mathbf{3 1}$ & Jumlah \\
\hline
\end{tabular}

Berdasarkan hasil test kemampuan peserta didik siklus I dapat dijabarkan halhal sebagai berikut :

$\checkmark$ Pada pertemuan I diperoleh 22 Siswa (70,79\%) tuntas, hanya 9 Siswa (16\%) Siswa yang tidak tuntas.

$\checkmark \quad$ Nilai rata-rata pertemuan I adalah 76,42.

$\checkmark \quad$ Nilai tertinggi pada pertemuan I sebesar 89 dan nilai terendah 72 .

$\checkmark$ Pada pertemuan II mengalami peningkatan yaitu 26 Siswa (84\%) tuntas, dan 5 Siswa $(16 \%)$ tidak tuntas

$\checkmark \quad$ Nilai rata-rata pada pertemuan II adalah 78,55.

$\checkmark \quad$ Nilai tertinggi pada pertemuan II sebesar 72 dan nilai terendah 50

$\checkmark$ Selisih peningkatan nilai rata-rata pada pertemuan I dan II yaitu 2,48.

$\checkmark \quad$ Nilai yang diperoleh masih belum sesuai dengan keinginan hal ini terjadi karena Siswa masih belum optimal dalam bekerja sama dalam melakukan kegiatan namun aktivitas Siswa sudah mulai membaik pada pertemuan ke II.

$\checkmark$ Karena respons Siswa sudah baik maka perangkat pembelajaran dan instrumen yang digunakan pada siklus II tetap sama seperti di siklus I.

b. Deskripsikan Hasil Siklus II

Berdasarkan hasil refleksi pada siklus I maka pelaksanaan tindakan pada siklus II dapat didefenisikan sebagai berikut :

1. Perencanaan Tindakan

Tahap perencanaan pada siklus II adalah Rencana Pelaksanaan Pembelajaran (RPP), Buku Siswa (merupakan kumpulan lembar ahli), Buku Guru, dan Lembar Kegiatan Siswa (LKS). Adapun materi yang dibahas dalam perangkat pembelajaran tersebut adalah menemukan karakteristik gelombang berjalan dan stasioner, menemukan rumus/persamaan gelombang berjalan dan gelombang stasioner, menemukan rumus atau persamaan hubungan cepat rambat rambat gelombang dan 
tegangan tali menggunakan percobaan Melde. Langkah-langkah pembelajaran yang disusun dalam RPP didesain sesuai dengan langkah-langkah dengan menggunakan model STAD.

2. Pelaksanaan Tindakan Siklus II

Pelaksanaan tindakan pada siklus II dapat deskripsikan sebagai berikut:

Peneliti memberikan tugas atas masing-masing beberapa kelompok.

$>$ Seluruh kelompok mengerjakan kegiatan sesuai dengan buku petunjuk.

$>$ Peserta didik diminta untuk melakukan eksperimen sesuai dengan yang ada di buku paket.

$>$ Peneliti memberi umpan balik hasil pemahaman peserta didik terhadap materi yang dipelajari dengan mengadakan evaluasi berupa tes.

$>$ Pendidik menilai hasil evaluasi.

$>$ Pendidik memberikan tindak lanjut.

3. Hasil Pengamatan (Observasi)

Pelaksanaan observasi pada kegiatan siklus II sama dengan kegiatan pada siklus I. Dalam hal ini observasi dilakukan oleh teman sejawat yaitu Guru sebagai observer. Observasi dilakukan untuk mengetahui keaktifan Siswa, kerja sama dan kecepatan dalam memahami materi. Hasil pengamatan siklus II dapat dideskripsikan sebagai berikut :

1) Pertemuan 1

Nilai hasil belajar pada pertemuan I bisa dilihat pada tabel 4 dibawah ini :

Tabel 4. Nilai Hasil Belajar Siklus II Pertemuan I

\begin{tabular}{cccccc}
\hline No & $\begin{array}{c}\text { Hasil } \\
\text { (angka) }\end{array}$ & $\begin{array}{c}\text { Hasil } \\
\text { (huruf) }\end{array}$ & Arti Lambang & $\begin{array}{c}\text { Jumlah } \\
\text { Siswa }\end{array}$ & Persen \\
\hline 1 & $85-100$ & A & Sangat baik & - & - \\
2 & $75-84$ & B & Baik & 24 & $77,42 \%$ \\
3 & $65-74$ & C & Cukup & 7 & $22,58 \%$ \\
4 & $55-64$ & D & Kurang & - & - \\
5 & $<=54$ & E & Sangat kurang & - & - \\
\hline & & & $\mathbf{3 1}$ & $\mathbf{1 0 0 \%}$ \\
\hline
\end{tabular}

Berdasarkan tabel 4 diperoleh 24 Siswa $(77,42 \%)$ mendapatkan nilai B, selebihnya yaitu 7 Siswa $(22,58 \%)$ mendapatkan nilai C.

2) Pertemuan 2

Nilai hasil belajar pada pertemuan II dapat dilihat pada tabel 5 sebagai berikut :

Tabel 5. Nilai Hasil Belajar Siklus II Pertemuan II

\begin{tabular}{cccccc}
\hline No & $\begin{array}{c}\text { Hasil } \\
\text { (angka) }\end{array}$ & $\begin{array}{c}\text { Hasil } \\
\text { (huruf) }\end{array}$ & Arti Lambang & $\begin{array}{c}\text { Jumlah } \\
\text { Siswa }\end{array}$ & Persen \\
\hline 1 & $85-100$ & A & Sangat baik & - & - \\
2 & $75-84$ & B & Baik & 28 & $90 \%$ \\
3 & $65-74$ & C & Cukup & 3 & $10 \%$ \\
4 & $55-64$ & D & Kurang & - & -
\end{tabular}




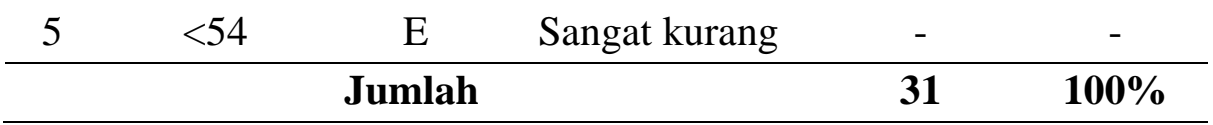

Berdasarkan tabel diatas diperoleh 28 Siswa atau 90\% Siswa mendapatkan nilai $\mathrm{B}$.

4. Refleksi

Nilai ketuntasan Siswa pada siklus II dapat dilihat pada pertemuan I dan II seperti pada tabel 6 sebagai berikut :

Tabel 6. Nilai ketuntasan Siklus II pertemuan I dan II

\begin{tabular}{cccccc}
\hline \multirow{2}{*}{ No } & \multirow{2}{*}{ Ketuntasan } & \multicolumn{2}{c}{ PETEMUAN I } & PETEMUAN II \\
& & Jumlah & Persen & & \\
1 & Tuntas & 24 & 77,42 & 1 & Tuntas \\
2 & Belum tuntas & 7 & 22,58 & 2 & $\begin{array}{l}\text { Belum } \\
\text { tuntas }\end{array}$ \\
\cline { 1 - 4 } & Jumlah & $\mathbf{3 1}$ & $\mathbf{1 0 0}$ & & \\
\hline
\end{tabular}

Berdasarkan hasil test kemampuan Siswa siklus II dapat dijabarkan sebagai berikut :

$\checkmark$ Siklus II diperoleh 28 Siswa (90\%) tuntas, dan 3 Siswa (10\%) tidak tuntas

$\checkmark$ Nilai tertinggi pada Siklus II sebesar 92 dan nilai terendah 72 .

$\checkmark$ Nilai rata-rata Siklus II adalah 78,55.

$\checkmark$ Siklus II mengalami peningkatan yang signifikan yaitu 28 Siswa (90\%) tuntas, 3 Siswa $(10 \%)$ tidak tuntas.

$\checkmark \quad$ Nilai tertinggi pada Siklus II sebesar 92 dan nilai terendah 71.

$\checkmark$ Nilai rata-rata pertemuan II adalah 76,52.

$\checkmark$ Dapat dikatakan hasil belajar Siswa sudah baik karena ada peningkatan hal ini menunjukkan perubahan langkah pembelajaran yang digunakan oleh Guru cukup efektif dalam memotivasi Siswa untuk lebih berani berpendapat.

$\checkmark$ Pada waktu kegiatan kelompok, Guru melatih Siswa dalam menjawab soal dibantu anggota kelompok yang lain agar mereka saling mempengaruhi, saling berkomunikasi, sharing dengan anggota kelompoknya. Penilaian akhir dilakukan Guru untuk mengetahui hasil latihan Siswa daengan kelompoknya berupa penilaian tampilan secara individu.

\section{Pembahasan}

Berdasarkan hasil penelitian pada siklus I diperoleh nilai Siswa yang berhasil tuntas sesuai dengan kriteria ketuntasan minimal (KKM 75) sebesar 22 Siswa $(70,97 \%)$ dan masih 9 Siswa $(29,03 \%)$ belum berhasil tuntas. Pada pertemuan kedua diperoleh 26 Siswa (84\%) dan masih 3 Siswa (16\%) belum berhasil tuntas. Maka dapat dikatakan masih banyak Siswa belum menguasai materi atau dapat dikatakan nilai hasil belajar materi gelombang mekanik. Hal ini terjadi karena pada siklus I masih banyak Siswa yang belum begitu memahami cara-cara melakukan kegiatan belajar serta Siswa masih enggan untuk bertanya kepada Guru. Selain itu Siswa juga masih belum faham dengan pendekatan STAD sehingga waktu banyak tidak efektif sesuai dengan apa yang direncanakan. 
Selanjutnya pada siklus II pertemuan terakhir diperoleh hasil yang memuaskan karena 28 Siswa atau $90 \%$ berhasil mendapatkan nilai diatas KKM. Hasil tersebut mengindikasikan bahwa rasa takut salah dan malu untuk bertanya sudah berkurang. Siswa mulai mau berbagi kepada teman-temannya, bahkan mereka juga sudah berani mengajukan saran atau mengomentari pendapat temannya yang keliru. Kalau diperhatikan tiap aktivitas, memang peningkatannya tidak seberapa besar. Tetapi kalau dilihat dari pengelompokan partisipasi aktif dan pasif, persentase tersebut cukup besar.

Berdasarkan hasil penelitian dapat ditarik kesimpulan adanya peningkatan hasil belajar Siswa pada materi gelombang mekanik dengan menggunakan model pembelajaran kooperatif tipe STAD (Student Team Achievement Division) bagi Siswa Kelas XI MIPA.6 semester II SMA Negeri 1 Mutiara tahun ajaran 2019/2020, menurut (Nazir Khan \& Muhammad Inamullah, 2011) peningkatan hasil belajar terjadi karena Guru menggunakan model pembelajaran dalam menyajikan materi gelombang mekanik dan menyesuaikan langkahlangkah kerja dalam penyusunan rencana pelaksanaan pembelajaran. Dengan melakukan kegiatan Siswa menjadi aktif serta materi mudah diingat selain itu belajar menjadi menyenangkan.

\section{PENUTUP}

Dari hasil kegiatan pembelajaran yang telah dilakukan dalam dua siklus dan berdasarkan pembahasan serta analisis, dapat diperoleh beberapa kesimpulan sebagai berikut:

1. Pembelajaran melalui metode kooperatif learning tipe STAD (Student Teams Achievement Division) memiliki dampak positif karena dapat meningkatkan hasil belajar Siswa yang ditandai dengan peningkatan ketuntasan belajar Siswa dari siklus ke siklus, pada siklus I tuntas sebanyak 22 orang, kemudian terjadi pula peningkatan ketuntasan belajar pada siklus II yaitu 28 Siswa dari 31 Siswa.

2. Pembelajaran dengan metode kooperatif learning tipe STAD (Student Teams Achievement Division) dapat meningkatkan keaktifan Siswa dalam belajar kelompok hal ini ditunjukkan adanya tanggung jawab kelompok dimana Siswa yang lebih mampu mengajar temannya yang kurang mampu.

3. Ada peningkatan hasil belajar Siswa pada materi gelombang mekanik melalui metode pembelajaran kooperatif learning tipe STAD (Student Teams Achievement Division) pada Siswa Kelas XI MIPA.6 semester II SMA Negeri 1 Mutiara Tahun Pelajaran 2019/2020. Berdasarkan simpulan dari hasil yang penulis capai dalam penelitian ini maka dapat penulis sarankan beberapa hal sebagai berikut:

1. Pada suatu proses pembelajaran hendaknya Guru menggunakan metode/pendekatan yang sesuai dengan materi yang akan diajarkan dan melakukan analisis materi pelajaran yang akan disampaikan serta berperan dalam mendampingi Siswa ketika proses pembelajaran berlangsung.

2. Dalam rangka meningkatkan hasil belajar Siswa Guru hendaknya lebih sering melatih Siswa dengan berbagai metode pengajaran yang sesuai walau dalam taraf sederhana. 


\section{DAFTAR PUSTAKA}

Arikunto. Suharsimi, dkk. 2008. Penelitian Tindakan Kelas. Jakarta: Bumi Aksara.

Barizi, Ahmad. 2009. Menjadi Guru Unggul, Bagaimana menciptakan pembelajaran yang Produktif \& Profesional. Jogjakarta: Ar-Ruzz Media.

Artini, N. M. (2020). Pembelajaran Model Stad Untuk Meningkatkan Prestasi Belajar Matematika Pada Siswa Kelas V Sdn 39 Cakranegara. Jurnal Paedagogy, 3(1), 30-37. https://doi.org/10.33394/JP.V3I1.3033

Barokati, N., \& Annas, F. (2013). Pengembangan Pembelajaran Berbasis Blended Learning pada Mata Kuliah Pemrograman Komputer (Studi Kasus: UNISDA Lamongan). Sistem Informasi, 4(5), 352-359. https://doi.org/10.24089/j.sisfo.2013.09.006

Esminarto, E., Sukowati, S., Suryowati, N., \& Anam, K. (2016). Implementasi Model Stad Dalam Meningkatkan Hasil Belajar Siwa. Briliant: Jurnal Riset Dan Konseptual, 1(1), 16. https://doi.org/10.28926/briliant.v1i1.2

Nazir Khan, G., \& Muhammad Inamullah, H. (2011). Effect of Student's Team Achievement Division (STAD) on Academic Achievement of Students. Asian Social Science, 7(12). https://doi.org/10.5539/ass.v7n12p211

Rizal, R. S., Wardani, N. S., \& Permana, T. I. (2021). Peningkatan Hasil Belajar Tematik Melalui Pembelajaran Daring dengan Model STAD Berbantuan Power Point di Sekolah Dasar. Jurnal Basicedu, 5(2), 1067-1075. https://doi.org/10.31004/basicedu.v5i2.873 